\title{
Demonstration of Eco-friendly IPM Modules for the Management of Major Sucking Pests in Cotton
}

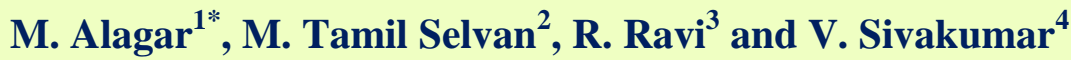 \\ ${ }^{1}$ Agricultural Entomology, ${ }^{4}$ Horticulture, \\ Coconut Research Station, TNAU, Aliyarnagar, India \\ ${ }^{2}$ Horticulture, Agricultural Research Station, TNAU, Pattukottai, India \\ ${ }^{3}$ Forestry, Forest College and Research Institute, TNAU, Mettupalayam, India \\ *Corresponding author
}

\section{A B S T R A C T}

Eco-friendly IPM module for the management of major sucking pests of cotton was demonstrated in the farmer's field. Eco-friendly IPM module

\section{Keywords}

Pest management, Eco-friendly, IPM module

Article Info

Accepted:

15 July 2020

Available Online:

10 August 2020 has significantly reduced the sucking pests population. The leafhoppers population was low (1.5 number / 3 leaves) in the demo plots and it was high (4.2 numbers/ 3 leaves) in the check plots. Similarly the aphids, thrips, whitefly and mealy bug population were low in the demo plots when compared to the check plots. The predator population viz., coccinellids, syrphids, green lace wing and spiders was high in the demo plots compared to very meager in the check plots. It indicated the harmful effect of pesticides on natural enemies. The number of pesticide spray was reduced completely in the demo plots but in the check plots the farmers sprayed five to six rounds chemical insecticides. The net return and benefit cost ratio was Rs.89,603/ha and 1:2.2 respectively in demo plot and it was only Rs.23,763/ha 1: 1.2 respectively in check plot.

\section{Introduction}

Cotton (Gossypium spp.) major commercial crop of global significance unanimously designated as "King of Fibres" is grown for its lint and seed in more than 70 countries of the world (Nagrare et al., 2013). India takes the privilege of growing all the four species of cotton on commercial scale. India is the largest cotton growing country in the world with area of more than 214 lakh hectares with a production of 370 lakh bales. However the productivity with $505 \mathrm{~kg} / \mathrm{ha}$ against world approximate average of $766 \mathrm{~kg}$ lint/ha (CICR, 2018).

In cotton about 184 insect pests have been recorded on cotton in India, causing 30-80\% 
loss to yield (Kranthi et al., 2009; Prashanth et al., 2018). This crop is known to consume about 55 per cent of toxic insecticides used in India. It is now an established fact that injudicious use of pesticides leads to several hazards such as development of resistance to insecticides. Destruction of natural enemies, alarming quantities of toxic residues of pesticides in food, water, soil etc. resulted in the serious problems of biological magnificence of pesticides through food chain (Murugan et al., 2003: Kranthi et al., 2009). After introduction of $\mathrm{Bt}$ cotton the pesticide consumption was reduced drastically but the sucking pest scenario was changed to higher level (Prashanth et al., 2018). Nowadays severe incidence of whitefly and mealybug, causes poor crop establishment and yield loss up to 20\% (Prashanth et al., 2018). Due to yield loss and lack of knowledge on ecofriendly pest management strategies among the cotton growing farmers, Front line demonstration (FLD) was conducted on 'Demonstration of Eco-friendly IPM modules for the management of major sucking pests in cotton at Nagapattinam district of Tamil Nadu.

\section{Materials and Methods}

FLD was conducted at Nagapattinam district of Tamil Nadu, India through ICAR-KVK, Sikkal during 2017-18. Nagapattinam district is located in Cauvery delta zone of Tamil Nadu and cotton is cultivated in 2633 hectares as rice fallow crop during February to June. The prioritized problems observed were reduction in natural enemies due to indiscriminate use of pesticides in cotton ecosystem and lack of knowledge on ecofriendly pest management strategies among the cotton growing farmers in the Nagapattinam district. Severe incidence of whitefly, leafhoppers and mealy bug causes poor crop establishment and yield reduction up to $20 \%$. To create awareness among the farmers there was 10 demonstrations were conducted, one acre each. In the demonstration plot the following technologies were demonstrated to manage the sucking pests in cotton. Spray of Azadiractin 1\% (10,000ppm) @1250ml/ha, spray of Fish Oil Rosin Soap (FORS) 25g/lit @ $12.5 \mathrm{~kg} / \mathrm{ha}$, installation of yellow sticky trap @12 no./ha, spray of Lecanicillium leccanii (containing $10^{8}$ conidia $\mathrm{g}^{-1}$ of formulation) @ $5 \mathrm{~kg} / \mathrm{ha}$ and relaease of parasitoid, Acerophagous papayae @ 500 no./ha for the management of mealy bug were done based on the ELT of sucking pests. We advised the farmers to grow cowpea as bund crop and maize as border crop to conserve the natural enemies in the field. We educated the farmers about the eco friendly IPM techonologies through on campus and off campus trainings. We suggested the farmers to follow the standard agronomic practices recommended by Tamil $\mathrm{Nadu}$ Agricultural University in the demonstration plot. In check plot the we did not intervined, the farmers adopted thier own package of practices to compare the impact of the technology.

\section{Assessment of sucking pest damage}

The population of leafhoppers, whitefly, thrips and aphids were counted from top, middle and bottom leaves from rondomly selected 10 plants from each demo and check plots. The population of mealy bug was counted from the five centimeter portion of infested branch of cotton plant. The grading system was followed as given by Monga et al., (2009) (0-No Mealy bug; I-About 1-10 Mealy bug scattered over the plant; II-One branch infested heavily with mealy bug; IIITwo or more branches infested with mealy bug, up to $50 \%$ plant affected and IVComplete plant affected). The population of sucking pests were counted at 30, 60 and 90 days after sowing. 


\section{Assessment of natural enemies population}

The populations of generalist predators like spiders, green lace wing and lady bird beetle and syrphids were also recorded from randomly selected 10 plants/plot, to study the beneficial effects of the treatments applied. These predators are associated with all sucking pests.

\section{Estimation of extension gap, technology gap and technology index}

The extension gap, technology gap and technology index were worked out. To estimate the technology gap, extension gap and technology index, following formulae given by Samui et al., (2000) was used.

Technology gap $=$ Potential yield $(q / h a)-$ Demonstration yield (q/ha)

Extension gap $=$ Demonstration yield $(\mathrm{q} / \mathrm{ha})-$ farmer's practice yield (q/ha).

Technology Index $=$ (Potential yield Demonstration yield) / Potential yield) x100

\section{Results and Discussion}

The results from the table 1 revealed that the Eco-friendly IPM module has significantly reduced the sucking pests population. The leafhoppers population was 1.5 number $/ 3$ leaves, when compared to the check plot where it was high (4.2 numbers/ 3 leaves). The aphids, thrips and whitefly population were $10.2,6.7,2.5$ number $/ 3$ leaves respectively in the demonstration plot, whereas it was $30.2,15.5,5.3$ number $/ 3$ leaves respectively in the check plot. The mealy bug damage grade was low (1.0) in the demonstration plot and it was high (3.5) in the check plot.

The predator population was high in the demonstration plot (Table 2) compared to very meager in the check plot. The predators like coccinellids, syrphids, green lace wing and spiders were observed. In the demonstration plot $3.5,1.5,1.5$ and 1.2 number/plant of coccinellids, syrphids, green lace wing and spiders respectively were observed. Whereas, in the check plot only very meager number of coccinellids $(0.1$ number /plant) and spiders (0.2 number/plant) were observed. Syrphids, green lace wing was not observed in the check plot. The number of pesticide spray was reduced completely in the demo plots but in the check plots the farmers sprayed 5 to 6 rounds chemical insecticides.

The yield was $31.2 \mathrm{q} / \mathrm{ha}$. in demo plot and it was $20.9 \mathrm{q} / \mathrm{ha}$. in check plots. The net return was Rs.89,603/ha in demo plot and it was only Rs.23,763/ha in check plot. The benefit cost ratio was high (1:2.2) in demo and it was only 1:1.2 in the check plot (Table 3 ).

The yield reduction of $8.2 \mathrm{q} / \mathrm{ha}$ recorded due to technology gap (Table 4). The latest technologies will eventually lead the farmers to discontinue the traditional technology and to adopt new technology. The difference of yield $10.3 \mathrm{q} / \mathrm{ha}$ obtained due to technology gap, during the period of study which emphasized the need to educate the farmers through various means for the adoption of improved agricultural production to reverse the trend of wide extension gap. The technology index was 8.2 percent which showed the feasibility of the evolved technology at the farmer's field. Tiwari et al., (2015) reported that the lower the value of technology index, the more is the feasibility of the technology.

The eco-friendly modules restricting the pest population below ETL by promoting the activity of natural enemies and reducing the quantum of pesticide applied on the crop. 
Table.1 Population of sucking pests in the Eco-friendly IPM module for cotton

\begin{tabular}{|l|c|c|}
\hline \multicolumn{1}{|c|}{ Parameter } & Demonstration plot & Check plot \\
\hline Leaf hopper (No/3 leaves) & 1.5 & 4.2 \\
\hline Aphids (No/3 leaves) & 10.2 & 30.2 \\
\hline Thrips (No/3 leaves) & 6.7 & 15.5 \\
\hline Whitefly (No/3 leaves) & 2.5 & 5.3 \\
\hline Mealybug (Grade) & 1.0 & 3.5 \\
\hline
\end{tabular}

Table.2 Major predator population in the Eco-friendly IPM module for cotton

\begin{tabular}{|l|c|c|}
\hline \multicolumn{1}{|c|}{ Predators } & Demonstration plot & Check plot \\
\hline Coccinellids (No/plant) & 3.5 & 0.1 \\
\hline Syrphids (No/plant) & 1.5 & 0 \\
\hline Green lace wing (No/plant) & 1.5 & 0 \\
\hline Spiders (No/plant) & 1.2 & 0.2 \\
\hline
\end{tabular}

* Mean of 10 demonstrations, from three observations and from 10 randomly selected plants / demo

Table.3 Comparative analysis of cost and returns in the demonstration and in check plot in cotton

\begin{tabular}{|l|c|c|}
\hline \multicolumn{1}{|c|}{ Parameter } & Demonstration plot & Check plot \\
\hline $\begin{array}{l}\text { Gross cost of cultivation } \\
\text { (Rs./ha) }\end{array}$ & 61,644 & 77,481 \\
\hline Yield (Quintal/ha) & 31.2 & 20.9 \\
\hline Gross income (Rs./ha) & 15,1247 & $1,01,243$ \\
\hline Net return (Rs./ha) & 89,603 & 23,763 \\
\hline BCR & $1: 2.2$ & $1: 1.2$ \\
\hline
\end{tabular}

* Mean of ten demonstrations

Table.4 Technology gap, extension gap and technology Index of Eco-friendly IPM module for cotton

\begin{tabular}{|c|c|c|c|c|c|}
\hline $\begin{array}{c}\text { Potential yield } \\
\text { (q/ha.) }\end{array}$ & $\begin{array}{c}\text { Demonstration } \\
\text { yield (q/ha.) }\end{array}$ & $\begin{array}{c}\text { Farmers } \\
\text { practice yield } \\
\text { (q/ha.) }\end{array}$ & $\begin{array}{c}\text { Technology } \\
\text { gap (q/ha.) }\end{array}$ & $\begin{array}{c}\text { Extension } \\
\text { gap (q/ha.) }\end{array}$ & $\begin{array}{c}\text { Technology } \\
\text { index (\%) }\end{array}$ \\
\hline $\mathbf{3 4}$ & 31.2 & 20.9 & 8.2 & 10.3 & 8.2 \\
\hline
\end{tabular}

* Mean of ten demonstrations 
These studies indicate that surely, ecofriendly IPM module had an advantage over non IPM module. The concepts of Ecofriendly pest management coupled with augmenting natural enemies developed by Jayaraj (1988), Natarajan, and Seshadri, (1988), Sundaramurthy and Basu (1985), Sundaramurthy (1990), Puri et al., (2005), Swamy et al., (2010), Balakrishnan et al., (2010), Pandher and Satnam, (2011) and Patil et al., (2011) also corroborates the results of the present study.

In conclusion, the results clearly indicated that the Eco-friendly IPM module significantly reduced the pest population and the increased the predator population proved the compatibility of this eco-friendly IPM module for the natural enemies. Eco-friendly IPM module for the management of major sucking pests in cotton is best alternative for the chemical pesticides.

\section{References}

Balakrishnan N, Murali Baskaran RK and Mahadevan NR (2010). Influence of intercrops/trap crops on the preference of major pests of cotton in different IPM modules under rainfed condition. Journal of Biopesticides, 3(1): 373-378.

CICR (2018). Area, Production and productivity of cotton in India, ICARCentral Institute for Cotton Research, Nagpur, Maharashtra. http://www.cicr.org.in/database/dbcapp 5.html

Jayaraj S (1988). The problem of Heliothis armigera in India and its integrated management. Proc. National Workshop on Heliothis armigera management. TNAU , Coimbatore, pp.18-19.

Kranthi KR, Kranthi S, Rameash K, Nagrare VS, Anupam Barik. (2009). Technical Bulletin: Advances in Cotton IPM. Central Institute for Cotton Research,
Nagpur, 2009.

Monga D, Kumar R, Pal V and Jat MC. (2009). Mealybug, new pest of cotton crop in Haryana: A survey. J. Insect Sci., 22: 101-103.

Murugan M, Sathiah N, Dhandapani N, Rabindra RJ, Mohan S (2003) Laboratory assays on the role of Indian transgenic Bt cotton in the management of Helicoverpa armigera (Hubner) (Noctuidae: Lepidoptera). Indian Journal of Plant Protection. 31:1-5.

Nagrare VS, Kranthi S, Kranthi KR, Chinna Babu Naik V, Rishi Kumar, Dharajothi 2013. Handbook of Cotton Plant Health. Central Institute for Cotton Research, Nagpur

Natarajan N and Seshadri V (1988). Abundance of natural enemies of cotton insects under intercropping system. $J$. Bioi. Cofllroi, 2 :3- 5.

Patil SB, Patil BV, Bvandal N, Hirekurubar RB and Udikeri SS (2011).

Development and validation of integrated pest management strategies for $\mathrm{Bt}$ cotton under rainfed ecosystem. Indian Journal of Agricultural Sciences, 81 (5): 450-454.

Pandher S and Satnam S. (2012). Comparative Evaluation of IPM Module and Eco-Friendly Strategies In BtCotton. Annals of Plant Protection Sciences. 20(1)1-3

Prashant W N, Kiran P, Budhvat and Pankaj SW. (2018) Population Dynamics of Sucking Pests with Relation to Weather Parameters in Bt Cotton in Buldana District, Maharashtra, India. Int.J.Curr.Microbiol.App.Sci., $\quad 7(1)$ : 620-626.

Puri SN, Sharma OP, Murthy KS, Lavekar RC (2005). Comparative Evaluation of Different IPM Modules in Rainfed Cotton of Maharashtra. Annals of Plant Protection Sciences. 13(1):100-104.

Samui SK, Mitra S, Roy DK, Mandal AK and 
Saha D. (2000). Evaluation of front line demonstration on groundnut. $J$ Indian Soc Coastal Agric Res 18(2) : 180-183

Sundaramurthy VT and Basu, AK (1985). Management of cotton insect pests in polycrop system in India. Out look on Agriculture. 14:79-82.

Sundaramurthy, V. T. 1990. Status of Heliothis in cotton and strategies for its management, pp.115-123. In: Proceedings of first national workshop on Heliothis management. Current Status and future strategies August,
1990; DPR, Kanpur.

Swamy, SVS, Gopala and Prasad, NVVSD (2010). Comparative evaluation of different Pest Management Strategies on Cotton. Annals of Plant Protection Sciences, 18(1): 131-135.

Tiwari B K, Tiwari K P, Sahare K V and Tripathi P N (2015). Impact of Front Line demonstration of management practices on wheat under irrigated conditions. Plant Archives 15 (2): 10791082.

\section{How to cite this article:}

Alagar, M., M. Tamil Selvan, R. Ravi and Sivakumar, V. 2020. Demonstration of Eco-friendly IPM Modules for the Management of Major Sucking Pests in Cotton. Int.J.Curr.Microbiol.App.Sci. 9(08): 1268-1273. doi: https://doi.org/10.20546/ijcmas.2020.908.143 